\title{
Evaluation of Jatropha curcas and Moringa oleifera Seedlings in Two Different Ecological Regions Cultivated on Different Distances
}

\author{
Safaa A. Ghorab , Nashwa H. Mohamed ${ }^{1}$ and Nader A. El-Shanhorey ${ }^{2}$
}

\begin{abstract}
Jatropha curcas L., a multipurpose shrub, planting in a marginal soil, it has gained lot of importance for the production of biodiesel. Moringa oleifera Lam., is a highly valued plant, it has an impressive range of medicinal uses with high nutritional value. The field experiment was carried out at Ismailia and Alexandria governorates, at east and west of Egypt, respectively. Jatropha and Moringa were cultivated from May 2013 to October 2015 under different ecological regions and two plant spacing $(0.5 \mathrm{~m} * 0.5 \mathrm{~m}$ and $1.0 \mathrm{~m} * 1.0 \mathrm{~m})$, to evaluate the productivity.

The results revealed that there was high significant different of the most of growth parameters of Jatropha and Moringa shrubs in Ismailia region as compared with Alexandria region. It was clear that, the amount of fruits, seeds and oil yield $\left(\mathrm{kg} \mathrm{ha}^{-1}\right)$ of Moringa were increased in 2015 as compared with 2014. Jatropha started to give fruits at 2015 in the both two regions, but it did not give fruits with wide spacing in Alexandria. The results also revealed that the highest values of fruits, seeds and oil yield were 2111, 621 and $82 \mathrm{~kg} \mathrm{ha}^{-1}$, respectively for Moringa with $0.5 \mathrm{~m} * 0.5 \mathrm{~m}$ spacing in Ismailia region. While, the lowest values of fruits, seeds and oil yield were 552,142 and $13 \mathrm{~kg} \mathrm{ha}^{-1}$, respectively for Moringa with $1.0 \mathrm{~m} * 1.0 \mathrm{~m}$ spacing in Alexandria. Also, the highest values of fruits and seeds yield were 191 and $105 \mathrm{~kg} \mathrm{ha}^{-1}$, respectively of Jatropha in Ismailia, while the highest value of squeeze oil percentage was $17.23 \%$ for jatropha with narrow spacing in Alexandria followed by Ismailia region.
\end{abstract}

It could be concluded that Ismailia region more suitable for planting Jatropha and Moringa especially with narrow spacing to give the highest amount of fruits, seeds and oil yield, but Alexandria region gave the highest oil percentage with Jatropha under narrow spacing.

Keywords: Jatropha curcas, Moringa oleifera, biodiesel, different ecological regions, spacing, oil yield

\section{INTRODUCTION}

\section{Jatropha curcas:}

Jatropha curcas belongs to the genus Jatropha which contain approximately 170 known species, family Euphorbiaceae. Jatropha curcas, is a shrub of up to $5 \mathrm{~m}$ tall, originates in Central America and Mexico, and has been naturalized in a number of other tropical and sub-tropical countries in Asia, Africa and Latin America, with the total plantation area estimated at
900,000 ha in 2008. It is a perennial shrub which resists a high degree of aridity and which can grow in most kinds of soils, even in desert and depleted soils thereby avoiding competition with food production, while at the same time helping in soil regeneration and erosion prevention (Jongschaap et al., 2007; Achten et al., 2008; IFAD-FAO, 2010; FAO, 2011 ).

Jatropha curcas is an oil seed producing species which has generated much interest due to its potential for bio-diesel production (IFAD-FAO, 2010), where, its production is positive in comparison to the use of fossil fuels (Silitonga et al., 2011). Seed yield and oil production of Jatropha can be related to a variety of factors such as climate, site quality, genetic and physiological quality of the seed used, the size of the plants used in the establishment phase and the intensity of management of the plantations. Jatropha plantations produce two seed crops annually, the first in spring (between April and May) and the second in autumn (between September and October). Seed production will be maintained over 30 - 50 years, FAO (2011); Heller (1996) and Tewari (2007).

Egypt has already cultivated Jatropha using treated wastewater at more than 400 hectare of margin lands (Ministry of Agriculture and land Reclamation Under secretariat for Afforestation \& Environment, 2009).

\section{Moringa oleifera:}

Moringa oleifera, a woody plant or shrub, offers opportunities for use in marginal lands. The species has low nutrient needs and requires little or no fertilizers, and also needs few or no pesticides when cultivated (Tilman et al., 2006). Moringa belongs to the family of Moringaceae which contains 13 species. The most widely known and used species is Moringa oleifera. The tree's height is up to 5 meters tall which is originates in the Himalayas in northwestern India. The species has been planted in tropical and subtropical climates throughout the tropics.

Moringa oleifera grows quickly in many types of environments, a highly drought-resistant, with minimum annual rainfall requirements estimated at $250 \mathrm{~mm}$. The species tolerates a wide variety of soils, with $\mathrm{pH}$ between 4.5 and 9.0; however, it prefers neutral to

${ }^{1}$ Forestry and Timber Trees Dept., Hort. Res. Inst.,

A. R. C., Egypt. (elnaggar_42@hotmail.com, nanosh28@yahoo.com)

${ }^{2}$ Botanical Gardens Dept., Hort. Res. Inst.,

A. R. C., Egypt. (dr_shanhorey@yahoo.com)

Received April 26 2016, Accepted August 25, 2016 
slightly acidic soils ( $\mathrm{pH}$ 6.3-7.0). The species is not frost tolerant (FAO, 2011). Where's Moringa oleifera do not need much watering, the trees will flower and produce pods whenever there is sufficient water available. If rainfall is continuous throughout the year, $M$. oleifera will have a nearly continuous yield. In arid conditions, flowering can be induced through irrigation. Temperature preferred by $M$. oleifera ranges between 25-35 degrees celsius (Ramachandran et al., 1980).

Biodiesel derived from Moringa oil is an acceptable substitute for petrodiesel when compared to biodiesel fuels derived from other vegetable oils (Rashid et al., 2008). Moringa oleifera is also widely known as coagulants within the scientific community, thus it can be utilized as a chemical coagulation/flocculation agent that treats wastewaters (Verma, 2012).

\section{Ecological requirements for Jatropha and Moringa}

Trees in natural populations usually exhibit large variation in growth (Harper, 1977). Understanding this variation in growth is central to forest ecology because of its significance to forest structure and biomass.

FAO Ecocrop (2011) summarized the Ecological requirements of Jatropha curcas and Moringa oleifera as follows: optimal rainfall $(\mathrm{mm})$ for both plants are 500- 1500 and 700- 2200, respectively, while absolute range are 300- 2000 and 400- 2600, respectively. Optimal temperature $\left({ }^{\circ} \mathrm{C}\right)$ range are $11-28$ and $20-35$, respectively when absolute range are 7- 36 and 7- 48 for Jatropha and Moringa. For soil $\mathrm{pH}$ the optimal rang are 5.5- 7.5, 5.5- 7 and absolute range are 5- 8, 5- 8.5. While, optimal and absolute soil salinity ranges $(\mathrm{dS} / \mathrm{m})$ are less than 4, for both plants, respectively. Also, (Palada and Changl, 2003; Amaglo, 2006; Da Amaglo et al., 2006; Schio, 2010) mentioned the similar environmental characteristics for both species. Therefore, both of $J$. curcas and $M$. oleifera are consume a little water compared to other crops used as biofuel feedstocks (WRC, 2008; Palada and Changl, 2003; Rashid et al., 2008; Radovich, 2009; Eijck, 2007) hence not expected to affect the soil water budget. So, the main objective of this study is to evaluate the growth and the productivity of J. curcas and M. oleifera in Alexandria and Ismailia regions with different plant spacing.

\section{MATERIALS AND METHODS}

\section{Location and description of study sites}

This study was carried out in two geographical sites during two seasons from 2013 to 2015.

\subsection{Alexandria site:}

Part of this study was carried out At Horticulture Research Institute (HRI) in Antoniades gardens which is located at the Southeastern of Alexandria city bounded by latitude $30^{\circ} 10^{\prime} 17.48 \mathrm{~N}$, and longitude $29^{\circ} 56^{\prime} 15.83 \mathrm{E}$, with a total area of about 120 feddans.

\subsection{Ismailia Site:}

Second part of the study was carried out at Ismailia Agriculture Research Station (IARS) that located in Ismailia governorate in the eastern parts of Arab Republic of Egypt (ARE) at the middle part of Suez Canal at latitudes $30^{\circ} 36^{\prime} 15 \mathrm{~N}$ and longitudes $32^{\circ} 16^{\prime}$ $20 \mathrm{E}$, with a total area of about 205 feddans.

\section{Soil properties:}

Soil analysis presented in Table (1) for Alexandria and Ismailia sites.

\section{Meteorology characterizes:}

Ismailia climate is characterized with 3 forms: cold warm winter for a long time, intermediate with light rains, moderate summer with some humidity, in general it is a moderate climate all over the year. The maximum monthly average for temperature is $35.1{ }^{\circ} \mathrm{C}$ in July and August. However, it is $19.9{ }^{\circ} \mathrm{C}$ in January. During night the temperature decreases and the minimum average limit is $7.1^{\circ} \mathrm{C}$ in January and $20.6^{\circ} \mathrm{C}$ in August. While, Alexandria has a semi-arid Mediterranean climate subtropical characterized by mild, variably rainy winters and hot, dry summers. January and February are the coldest months with daily maximum temperatures typically ranging from $12^{\circ} \mathrm{C}$ to $18^{\circ} \mathrm{C}$. Alexandria experiences violent storms, rain and sometimes hail during the cooler months. July and August are the hottest and most humid months of the year with an average daily maximum temperature of $30^{\circ} \mathrm{C}$. Autumn and spring have temperatures average about $22^{\circ} \mathrm{C}$. (World Meteorological Organization (UN) 27-09-2009. Meteorology characterizes for both sites presented in Table (2).

Table 1. The physical and chemical properties of the used mixture soil for the two regions

\begin{tabular}{|c|c|c|c|c|c|c|c|c|c|c|}
\hline \multirow{2}{*}{$\begin{array}{l}\text { Soil } \\
\text { sample }\end{array}$} & \multirow[b]{2}{*}{ pH } & \multirow{2}{*}{$\begin{array}{c}\text { EC } \\
\text { ds/m }\end{array}$} & \multicolumn{4}{|c|}{ Cations (meq/l) } & \multicolumn{3}{|c|}{ Anions (meq/l) } & \multirow{2}{*}{ Texture } \\
\hline & & & $\mathrm{Ca}^{++}$ & $\mathbf{M g}^{++}$ & $\mathrm{Na}^{+}$ & $\mathbf{K}^{+}$ & $\mathrm{HCO}_{3}^{-}$ & $\mathrm{Cl}^{-}$ & $\mathrm{SO}_{4}^{--}$ & \\
\hline Ismailia & 7.92 & 0.178 & 0.6 & 0.4 & 0.31 & 0.16 & 0.75 & 0.5 & 0.22 & Sandy soil \\
\hline Alexandria & 8.10 & 3.53 & 13.22 & 11.20 & 13.91 & 4.49 & 7.23 & 11.90 & 17.15 & $\begin{array}{c}\text { Clay sandy } \\
\text { loam }\end{array}$ \\
\hline
\end{tabular}


Table 2. Mean of the meteorological data at Central Laboratory of Agricultural Climate (CLAC) under the circumstances of Alexandria and Ismailia through the experiment from 2013 to 2015

\begin{tabular}{lcccc}
\hline \multirow{2}{*}{ Months } & \multicolumn{2}{c}{ Alexandria } & \multicolumn{2}{c}{ Ismailia } \\
\cline { 2 - 5 } & $\begin{array}{r}\text { Mean temperature } \\
\mathbf{(} \mathbf{C})\end{array}$ & $\begin{array}{c}\text { Mean Humidity } \\
(\mathbf{\%})\end{array}$ & $\begin{array}{c}\text { Mean temperature } \\
\mathbf{(} \mathbf{C})\end{array}$ & $\begin{array}{c}\text { Mean Humidity } \\
(\mathbf{\%})\end{array}$ \\
\hline January & 13.15 & 74.35 & 13.25 & 60.85 \\
\hline February & 14.10 & 71.35 & 14.40 & 57.75 \\
\hline March & 16.65 & 66.20 & 17.30 & 52.25 \\
\hline April & 19.35 & 64.30 & 21.60 & 45.95 \\
\hline May & 23.10 & 67.60 & 26.00 & 47.15 \\
\hline June & 25.65 & 69.55 & 27.60 & 53.95 \\
\hline July & 27.40 & 71.70 & 28.55 & 58.30 \\
\hline August & 28.15 & 71.15 & 29.40 & 53.60 \\
\hline September & 26.15 & 68.40 & 26.95 & 56.80 \\
\hline October & 23.35 & 69.50 & 23.70 & 58.80 \\
\hline November & 20.45 & 73.95 & 20.90 & 61.55 \\
\hline December & 15.35 & 72.60 & 15.30 & 58.60 \\
\hline
\end{tabular}

\section{Experimental treatments description:}

Seeds of two shrubs species Jatropha curcas and Moringa oleifera were sowed in the nursery at two geographical sites (Alexandria \& Ismailia) government in May 2013 then planted in land in September 2013, at two plant spacing treatment. Treatment $(0.5 \mathrm{~m} * 0.5 \mathrm{~m})$ planted in area $\left(24 \mathrm{~m}^{2}\right)$ for both species and $(1 \mathrm{~m} * 1 \mathrm{~m})$ treatment planted in area of $\left(40 \mathrm{~m}^{2}\right)$ for each species; Plants were distributed at three replicates. Plants were surface irrigated with fresh water three times a week in summer and twice a week in winter.

\subsection{Data recorded:}

\subsubsection{Vegetative growth parameters:}

Plant height $(\mathrm{cm})$, stem diameter $(\mathrm{cm})$ was measured three times per season in June, September and December of all planted area; data were used for growth curve. While, the data at three periods (2013, 2014 and 2015) were used for statistical analysis.

Three plants of each species and treatment were selected randomly for calculating fresh and dry weight of leaves, stem, root, fruits and total plant weight (gm) at the end of each season $(2014,2015)$.

\subsubsection{The percentage of fruiting Shrubs:}

The percentage of fruiting Shrubs determined by the following equation:

The percentage of fruiting Shrubs=(the number of fruiting shrubs/total number of shrubs)x 100

Fruits collected in September of 2014 and 2015 seasons.

\subsubsection{Squeezed oil yield:}

The shrub seeds were squeezed by a compressor (KT23-100EL). Oil percentage per (100 g) seeds was measured and then calculated per hectare.

\subsection{Data analysis:}

Experimental layout design was split- split plot with three replicates. Ten plants were chosen randomly from each replicate for data analysis. The main plots were sites, sub plots were tree species, while sub- sub plots were plant spacing. Means of the individual factors and their interaction were compared by L.S.D test at 5\% level of probability according to Snedecor and Cochran (1989).

\section{RESULTS AND DISCUSSIONS}

\section{Growth parameters}

\subsection{Plant height}

Trends for height growth of $J$. curcas and $M$. oleifera for Ismailia and Alexandria regions are shown in figure (1-A and B). At 2013, 2014 and 2015 periods, the results indicated a high increase in the growth with high significant variation in height between the two species at all assessment, as shown in table (3). However, at the end of the experiment in 2015, no significant variation in plant height was observed for the two regions and plant spacing. Also, there was a highly significant difference for the two regions, species and spacing interaction. The mean Moringa height was $219.16 \mathrm{~cm}$ and $319.63 \mathrm{~cm}$ for Alexandria region for wide and narrow spacing, respectively. Hence, the mean height of Jatropha was $93.7 \mathrm{~cm}$ for Alexandria and $138.4 \mathrm{~cm}$ for Ismailia with wide spacing. 
It is interesting to note that at many assessment in both sites, Ismailia region showed superiority in height growth (50.99, 160.77 and196.11 for 2013, 2014 and 2015, respectively) as compared with Alexandria region (27.21, 54.64 and 187.43, respectively). M. oleifera species gave the highest significant values 51.97, 151.68 and $267.54 \mathrm{~cm}$, respectively through 2013,2014 and 2015 , respectively as compared with $J$. curcas 26.24, 63.73 and 115.99, respectively.

Generally, the significant differences in the height growth of shrubs at Ismailia site specially, at 2013 and 2014 could be attributable to provenance difference in tolerance to arid/semiarid conditions of study site (Edward et al., 2006). The excellent performance of
Ismailia site is an indication of better adaptation to region condition for both of the two species. In addition the low salinity of the soil in Ismailia region as compared with Alexandria region as indicated in table (1).

On the other side, the data in figure (1-A and B) and table (3) indicated that closer plant spacing resulted into higher plant height $(199.36 \mathrm{~cm})$ than wider plant spacing $(184.17 \mathrm{~cm})$ due to the competition for the light, this results correlated with the finding of Kalannaver et al.(2009), Ghosh et al.(2006) and Fagam et al.(2012). Results elsewhere indicated that the growth and development of Jatropha is significantly affected by plant spacing (Evangelista, 2009).
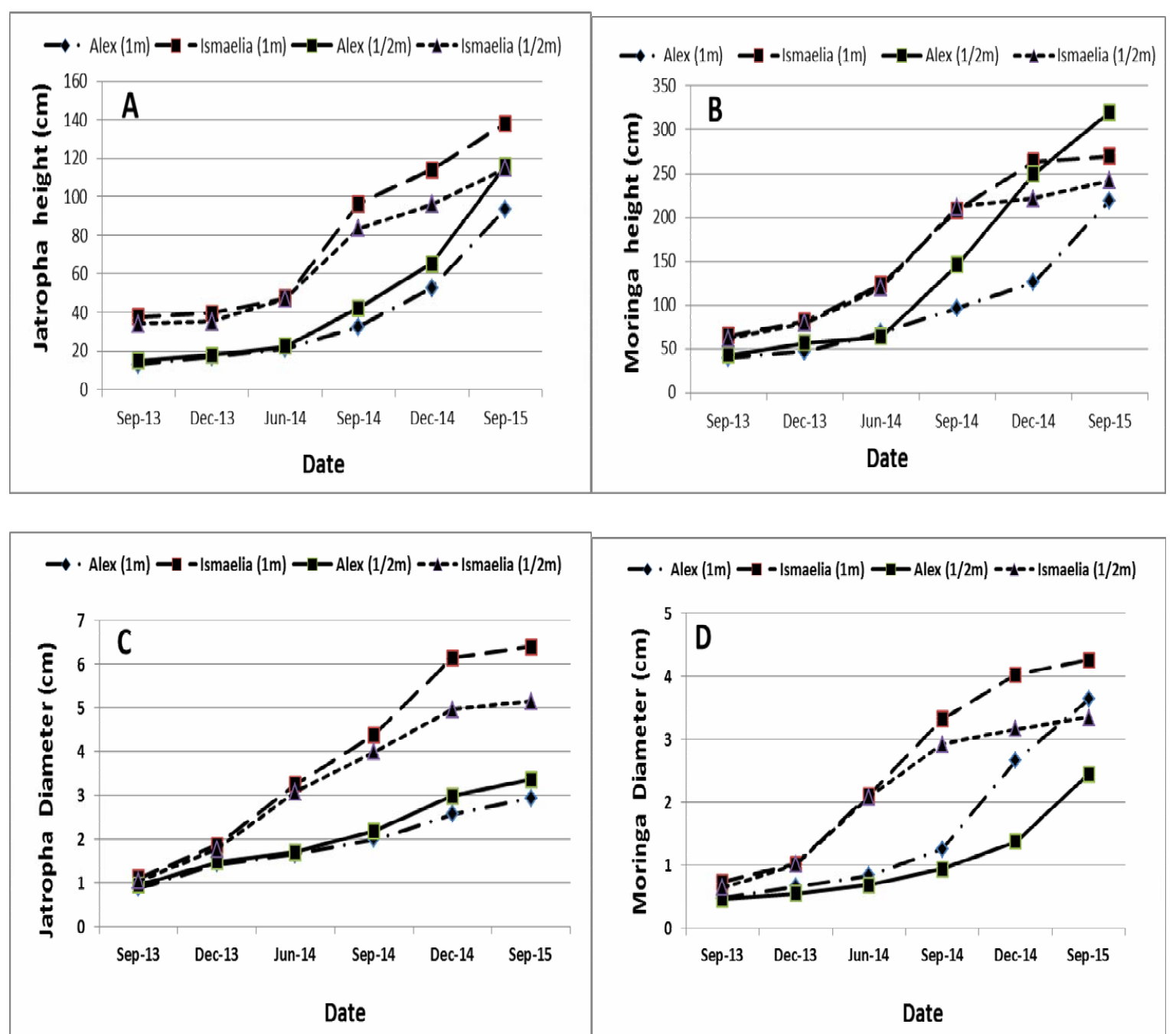

Figure 1. Growth of of Jatropha curcas and Moringa oleifera affected by different regions and different plant spacing from 2013 till 2015 


\subsection{Stem diameter}

Data in figure (1, C and D) and table (3) showed the behaviour of stem diameter $(\mathrm{cm})$ during the study period. At 2013 and 2014 periods a gradual increase and a significant difference can be seen in diameter especially for the two regions and species. While, there was no significant differences in diameter at 2013 and 2014 due to spacing. These results approved with the results of Fagam et al. (2012), which indicated that the effect of plant spacing on the canopy diameter of $J$. curcas was not significant. Although, the results at 2015 indicated that there was a significant differences between the regions, species, and plant spacing and the interaction between them. On the other side, the superior stem diameter was $6.40 \mathrm{~cm}$ for $J$. curcas in Ismailia region with wide spacing. While, the lowest stem diameter was $2.44 \mathrm{~cm}$ for $M$. oleifera in Alexandria region with narrow spacing (Table 3).

The differences in diameter development could be attributed to variations in adoptability among the regions, but Ismailia region showed low soil salinity and good climatic conditions for both the two species (Table 1\& 2).

\section{The productivity}

\subsection{Fruit weight}

Results in table (3) show the variation between the amount of fruits per shrubs through 2014 and 2015 seasons. It was clear that, $M$. oleifera was fast growth shrubs in Ismailia region because; it started to give fruits at 2014 season. While, the same species started to give fruits at 2015 season in Alexandria region. In the opposite, J. curcas started to give fruits in 2015 season in the two regions, but it did not give fruits with wide spacing in Alexandria. Considering, the amount of fruit was highly significant variations between the two species. Hence, at 2015 season, the highest amount of fruits (138.33 gm/ shrub) was of M. oleifera with wide spacing in Ismailia. While, the lowest amount of fruits (8.46 gm/ shrub) was of $J$. curcas with narrow spacing in Alexandria. De Avila (1949) found that distance (2.7 by $2.7 \mathrm{~m}$ ) may be more desirable for commercial cultivation of $J$. curcas because wider spacing is reported to increase crop yield by increasing fruit size. While, Silva et al. (2011) claimed that, as plant adapt to environmental conditions, the number of fruits will increase and, therefore, the productivity will also increase.

\subsection{Hundred seed weight}

The data in Table (3) showed significant effect due to region, species and spacing in the weight of hundred seeds and the interaction between the three previous factors is highly significant. Also, the data indicated that Jatropha curcus cultivated in Alexandria with narrow space recorded the highest mean value of hundred seeds weight (62.58 g). Whereas, Moringa oleifera cultivated in Ismailia with wide space recorded the lowest mean weight for hundred seeds weight $(35.18 \mathrm{~g})$ with significant difference between the two values. In addition, the data showed that $J$. curcus cultivated in Ismailia with narrow and wide space recorded 53.96 and $54.94 \mathrm{~g}$ for hundred seeds weight, respectively, while $M$. oleifera cultivated in the same region with narrow space recorded $35.58 \mathrm{~g}$.

For Alexandria region, $M$. oleifera recorded $40.78 \mathrm{~g}$. and $40.38 \mathrm{~g}$ for narrow and wide space respectively. Whereas, J. curcus with wide space did not give any seeds in the same region.

The previous results showed that Alexandria region is more suitable for hundred seeds weight for the two species than Ismailia region. So, this may be due to increase in photosynthetic activity that increases accumulation of metabolic substances, which directed impact on seed weight (Reddy et al. 1996). However, Shams et al. (1967) and Ögütçü (1980) reported that lesser thousand seed weight in Castor bean plant may be due to different plant material and environmental conditions. Terren et al. (2012) found that Jatropha seeds are often small and poorly filled. Also, Achten et al. (2010) showed that the weight of 1000 seeds rarely exceeds $500 \mathrm{~g}$. These results agree with our results because we get mean values of 42.87 and $37.98 \mathrm{~g}$ for Jatropha and Moringa respectively (table 3).

\subsection{Squeezed oil percentage}

According to the analysis of variance (Table 3) the squeezed crude oil percentage responded significantly to the effect of the regions, species and spacing. Also, the interaction between these three parameters is highly significant. Jatropha curcus planted in Alexandria with narrow space recorded the highest mean value of squeezed oil percent (17.27\%) followed by Moringa oleifera cultivated in Ismailia with narrow and wide space (13.19\%), followed by Jatropha curcus cultivated in the same region with narrow space $(12.89 \%)$ and wide space (12.88\%). In addition, Moringa oleifera in Alexandria with wide space give mean value of $(9.10 \%)$. Whereas, the same species with narrow space in the same region give the lowest mean value of squeezed oil percent (6.1\%). Deng et al. (2010) and Heller (1996) reported that Jatropha seeds contain 25$40 \%$ oil by weight. The average Jatropha oil content is $35 \%$ frequently quoted in the literature of Achten et al. (2008). While, Amouri et al. (2012) found that Moringa seeds contain $33-41 \%$ oil. 
Table 3. Mean values of seedlings height $(\mathrm{cm})$, stem diameter(cm), fruit weight $(\mathrm{gm} / \mathrm{shrub})$, 100 seed weight(gm) and oil percentage(\%) of Jatropha curcas and Moringa oleifera affected by different regions and different plant spacing

\begin{tabular}{|c|c|c|c|c|c|c|c|c|c|c|}
\hline \multirow[t]{2}{*}{ Treatments } & \multicolumn{3}{|c|}{$\begin{array}{c}\text { Plant height } \\
\text { (cm) }\end{array}$} & \multicolumn{3}{|c|}{$\begin{array}{l}\text { Stem diameter } \\
(\mathrm{cm})\end{array}$} & \multicolumn{2}{|c|}{$\begin{array}{c}\text { F.w } \\
(\text { gm/shrub) }\end{array}$} & \multirow{2}{*}{$\begin{array}{c}100 \text { S. W. } \\
\text { (gm) }\end{array}$} & \multirow{2}{*}{$\begin{array}{l}\text { Oil } \\
(\%)\end{array}$} \\
\hline & 2013 & 2014 & 2015 & 2013 & 2014 & 2015 & 2014 & 2015 & & \\
\hline \multicolumn{11}{|l|}{ Regions } \\
\hline Ismailia & 50.99 & 160.77 & 196.11 & 0.88 & 3.67 & 4.91 & 47.2 & 64.94 & 44.91 & 13.03 \\
\hline Alexandria & 27.21 & 54.64 & 187.43 & 0.69 & 1.59 & 3.09 & 0 & 43.62 & 35.93 & 8.87 \\
\hline F.test & $* *$ & $* *$ & N.S & $*$ & $* *$ & $* *$ & $* *$ & N.S & $* *$ & ** \\
\hline L.S.D 5\% & 0.61 & 32.43 & - & 0.15 & 0.54 & 0.72 & 11.83 & - & 1.51 & 0.07 \\
\hline \multicolumn{11}{|l|}{ Shrubs species } \\
\hline Jatropha curcas & 26.24 & 63.73 & 115.99 & 1.002 & 3.14 & 4.46 & 0 & 10.39 & 42.87 & 10.76 \\
\hline Moringa oleifera & 51.97 & 151.68 & 267.54 & 0.57 & 2.12 & 3.55 & 47.2 & 98.17 & 37.98 & 11.14 \\
\hline F.test & $* *$ & $* *$ & $* *$ & $* *$ & $* *$ & $*$ & $* *$ & $* *$ & $* *$ & $* *$ \\
\hline L.S.D 5\% & 3.32 & 28.56 & 39.47 & 0.103 & 0.48 & 1.33 & 7.64 & 52.44 & 0.65 & 0.05 \\
\hline \multicolumn{11}{|l|}{ Plant spacing } \\
\hline $0.5 \mathrm{~m} * 0.5 \mathrm{~m}$ & 39.09 & 95.71 & 199.36 & 0.77 & 2.51 & 3.58 & 21.48 & 45.48 & 48.22 & 13.11 \\
\hline $1 \mathrm{~m} * 1 \mathrm{~m}$ & 39.12 & 119.7 & 184.17 & 0.80 & 2.75 & 4.42 & 25.71 & 63.08 & 32.62 & 8.79 \\
\hline F.test & N.S & $* *$ & N.S & N.S & N.S & $* *$ & N.S & N.S & $* *$ & $* *$ \\
\hline L.S.D 5\% & - & 14.01 & - & - & - & 0.233 & - & - & 0.23 & 0.05 \\
\hline \multicolumn{11}{|l|}{ Interaction } \\
\hline Reg.1XSh.1 & 38.86 & 90.10 & 126.53 & 1.08 & 4.18 & 5.76 & 0 & 16.54 & 54.45 & 12.88 \\
\hline Reg.1XSh.2 & 63.13 & 231.44 & 265.68 & 0.68 & 3.15 & 4.06 & 94.4 & 113.33 & 35.38 & 13.19 \\
\hline Reg.2XSh.1 & 13.61 & 37.36 & 105.46 & 0.91 & 2.09 & 3.15 & 0 & 4.23 & 31.29 & 8.63 \\
\hline Reg.2XSh.2 & 40.81 & 71.93 & 269.4 & 0.47 & 1.09 & 3.04 & 0 & 83.01 & 40.58 & 9.1 \\
\hline F.test & N.S & $* *$ & N.S & N.S & N.S & $*$ & $* *$ & N.S & $* *$ & $* *$ \\
\hline L.S.D 5\% & - & 40.39 & - & - & - & 1.89 & 10.8 & - & 0.92 & 0.08 \\
\hline Reg.1XSp.1 & 49.75 & 146.57 & 180.33 & 0.84 & 3.46 & 4.27 & 0 & 49.73 & 44.77 & 13.04 \\
\hline Reg.1XSp. 2 & 52.24 & 174.97 & 211.89 & 0.92 & 3.87 & 5.55 & 0 & 80.14 & 45.06 & 13.03 \\
\hline Reg.2XSp.1 & 28.43 & 44.86 & 218.39 & 0.7 & 1.56 & 2.9 & 42.97 & 41.22 & 51.68 & 13.18 \\
\hline Reg.2XSp.2 & 26 & 64.43 & 156.46 & 0.68 & 1.62 & 3.29 & 51.42 & 46.01 & 20.19 & 4.55 \\
\hline F.test & N.S & N.S & $* *$ & N.S & N.S & $* *$ & N.S & N.S & $* *$ & $* *$ \\
\hline L.S.D 5\% & - & - & 25.92 & - & - & 0.329 & - & - & 0.32 & 0.077 \\
\hline Sh.1XSp. 1 & 26.33 & 62.93 & 115.9 & 1.002 & 3.09 & 4.24 & 0 & 9.8 & 58.27 & 15.08 \\
\hline Sh.1XSp. 2 & 26.14 & 64.53 & 116.09 & 1.001 & 3.18 & 4.67 & 0 & 10.97 & 27.47 & 6.44 \\
\hline Sh.2XSp. 1 & 51.84 & 128.50 & 282.82 & 0.55 & 1.93 & 2.93 & 42.97 & 81.15 & 38.18 & 11.14 \\
\hline Sh.2XSp. 2 & 52.09 & 174.87 & 252.26 & 0.603 & 2.31 & 4.17 & 51.42 & 115.18 & 37.78 & 11.14 \\
\hline F.test & N.S & $* *$ & N.S & N.S & N.S & $* *$ & N.S & N.S & $* *$ & $* *$ \\
\hline L.S.D 5\% & - & 19.82 & - & - & - & 0.32 & - & - & 0.32 & 0.07 \\
\hline Reg.1XSh.1XSp.1 & 38.07 & 83.67 & 114.64 & 1.05 & 3.99 & 5.13 & 0 & 11.14 & 53.96 & 12.89 \\
\hline Reg.1XSh.1XSp.2 & 39.65 & 96.53 & 138.42 & 1.12 & 4.38 & 6.40 & 0 & 21.95 & 54.94 & 12.88 \\
\hline Reg.1XSh.2XSp.1 & 61.43 & 209.47 & 246.01 & 0.64 & 2.93 & 3.42 & 85.95 & 88.33 & 35.58 & 13.19 \\
\hline Reg.1XSh.2XSp.2 & 64.83 & 253.41 & 285.36 & 0.73 & 3.36 & 4.71 & 102.85 & 138.33 & 35.18 & 13.19 \\
\hline Reg.2XSh.1XSp.1 & 14.60 & 42.20 & 117.16 & 0.95 & 2.19 & 3.36 & 0 & 8.46 & 62.58 & 17.27 \\
\hline Reg.2XSh.1XSp.2 & 12.63 & 32.53 & 93.76 & 0.88 & 1.99 & 2.94 & 0 & 0 & 0 & 0 \\
\hline Reg.2XSh.2XSp.1 & 42.26 & 47.52 & 319.63 & 0.46 & 0.94 & 2.44 & 0 & 73.98 & 40.78 & 6.1 \\
\hline Reg.2XSh.2XSp. 2 & 39.36 & 96.33 & 219.16 & 0.47 & 1.25 & 3.64 & 0 & 92.03 & 40.38 & 9.1 \\
\hline F.test & N.S & N.S & $* *$ & N.S & N.S & $* *$ & N.S & N.S & $* *$ & $* *$ \\
\hline L.S.D 5\% & - & - & 36.66 & - & - & 0.46 & - & - & 0.46 & 0.109 \\
\hline ** Highly significa & & ignifical & $\mathrm{NS}$ & Jon si & ificant & & & & & \\
\hline
\end{tabular}

Regions: Reg. 1: Ismailia Reg. 2: Alexandria Shrubs species: Sh. 1: Jatropha curcas Sh. 2: Moranga oleifera Plant spacing: Sp. 1: $0.5 \mathrm{~m} * 0.5 \mathrm{~m} \quad$ Sp. $2: 1 \mathrm{~m} * 1 \mathrm{~m}$ 
These highly percent of oil than our results perhaps due to the sample age of our young shrubs we used in our study. In general, narrow spacing increased oil content as compared with wide spacing.

\section{Biomass}

\subsection{Fresh weight}

The analysis of variance for leaves, stem, root, fruits and total fresh weight is shown in table (4). Regions, species and plant spacing effected on leaves, stem, root, fruits and total fresh weight significantly, especially at the first season (2014). Also, there was a significant effect for species and plant spacing interaction on leaves, stem, fruits, roots and total fresh weight. However, at the end of the experiment in 2015, there was no significant variation in leaves, root, fruits and total fresh weight due to the interaction between region, species and plant spacing. On the other side, the total fresh weight gave superior values $(3078.5,3025.8$ and $3057.3 \mathrm{gm})$ at Ismailia, M. oleifera and wide plant spacing, respectively. Hence, the superior value of total fresh weight was in Ismailia, with M. oleifera and wide plant spacing interaction in the first and second seasons (3332.5 and 4722.7, respectively).

\subsection{Dry weight}

The results for dry weight of two species under two locations and two plant spacing are presented in table (4). Regions, species and plant spacing affected significantly on leaves, stem, root, fruits and total dry weight especially through 2015 seasons. While, at 2014 season, the interaction between region and species were not differed in stem, root and total dry weight. Also, the interaction between regions and plant spacing were not differed significantly in leaves, stem and total dry weight. At the end of the experiment (2015), it was clear that total dry weight gave the highest values (1151.6, 1011.3 and $1055.7 \mathrm{gm}$,) at Ismailia region, $M$. oleifera and wide spacing, respectively. However, the interaction between regions, species and plant spacing was not significant in affecting the dry matter production in Jatropha and Moringa in the two seasons. Generally, the two species grown at Ismailia site with wide spacing showed high production of leaves, stem, root, fruits and total dry weight than those grown at Alexandria site (Table 4). This could be due to sufficient availability of growth resources (soil, temperature and humidity Table (1\&2)). The highest values in leaves, stem, root, fruits and total dry weight were $(85.62,507.5,370,110$ and $1151.6 \mathrm{gm}$, respectively). While, the lowest values in leaves, stem, root, fruits and total dry weight were (27.0, 204.0, 145.6, 26.6 and $403.2 \mathrm{gm}$, respectively) at Alexandria site. This poor performance could probably be due to poor genetic adaptation influenced by climatic conditions in these areas (Edward et al., 2013). On the other side, the widest plant spacing produced the highest dry matter than the narrow spacing, and there was a highly significant difference between them. On the contrary Edward et al. (2013) found that biomass of Moringa oleifera decreased with increasing spacing in both study sites. Bernardo et al. (1999) also noted that as spacing increase, total biomass production per hectare decrease. Evangelista (2009); Khrishna et al.(2008); Saxena et al.(2001) reported that the growth parameters like plant height, number of leaves, leaf area and dry matter yield were significantly affected by fertilizer types and levels and plant population.

\subsection{The total yield of fruit, seed and oil}

The relationship between regions, species and plant spacing and there effects on fruits, seeds and oil yield were take the same trend, and the yield of Moranga fruits, seeds and oil increased in Ismailia as compared with Alexandria of two spacing. Data in table (5) indicated that the highest values of fruits, seeds and oil yield were 2111,621 and $82 \mathrm{~kg} \mathrm{ha}{ }^{1}$, respectively for Moranga in Ismailia with narrow spacing. On the other side, the amount of Jatropha fruits and seeds were superior in Ismailia as compared with Alexandria region. While, the superior Jatropha oil yield (14 kg $\left.h \bar{a}^{1}\right)$ was recorded for Alexandria followed by Ismailia region (13.3 kg hă $\left.\bar{a}^{1}\right)$ with narrow spacing. Generally, decreasing plant spacing led to increasing fruits, seeds and oil yield for the two species in the two regions through the first and second seasons and may be the narrow spacing led to the competition between shrubs caused increased fruits seeds and oil. So, it could expand the cultivation area. Achten et al. (2008) found that the seed yield of mature Jatropha ranged between 9.8-12.3 t. hā $\bar{a}^{1}$ of dry seed is a reasonable yield estimate for an adequately managed plantation with favourable environment conditions. Amouri et al. (2012) showed that the seeds and oil yield of mature Moringa oleifera ranged between 3-6(t/ ha) and 0.99-2.46(t/ ha), respectively. However, Jatropha curcas seed yield ranged between 0.94- 2.35(t/ ha). While, Terren et al. (2012) found that the average seed yield obtained at Senegal after four years of cultivation less than $500 \mathrm{~kg}$ $h^{1}{ }^{1}$ of dry seed. These results are very high when compared with our results, this may be our shrubs are still young and it did not reach to the maturity age.

\subsection{Fruiting Shrubs percentage}

There was a high variation in the fruiting shrubs percentage in the first season (2014) as compared with the second season (2015) as shown in table (5). 


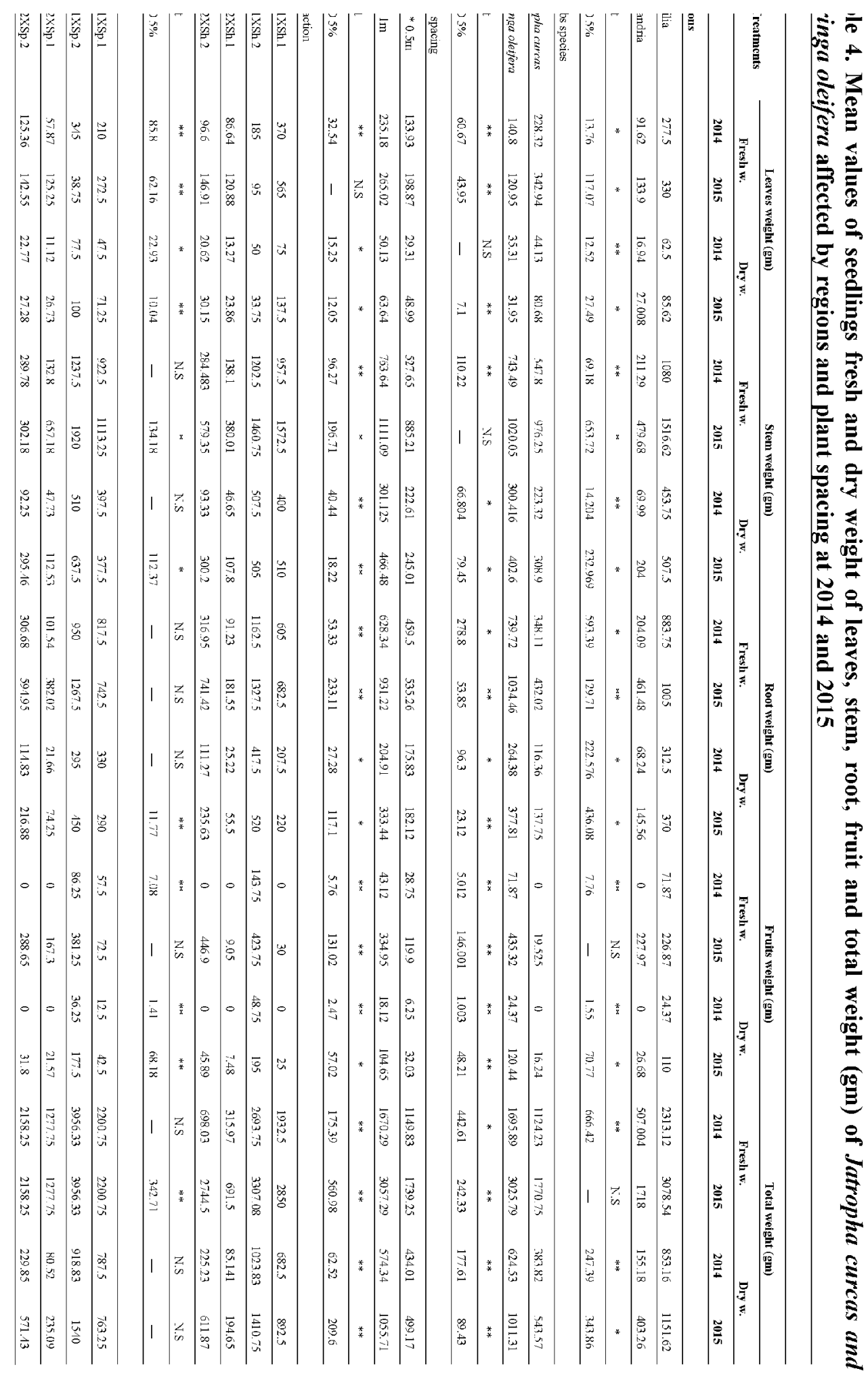




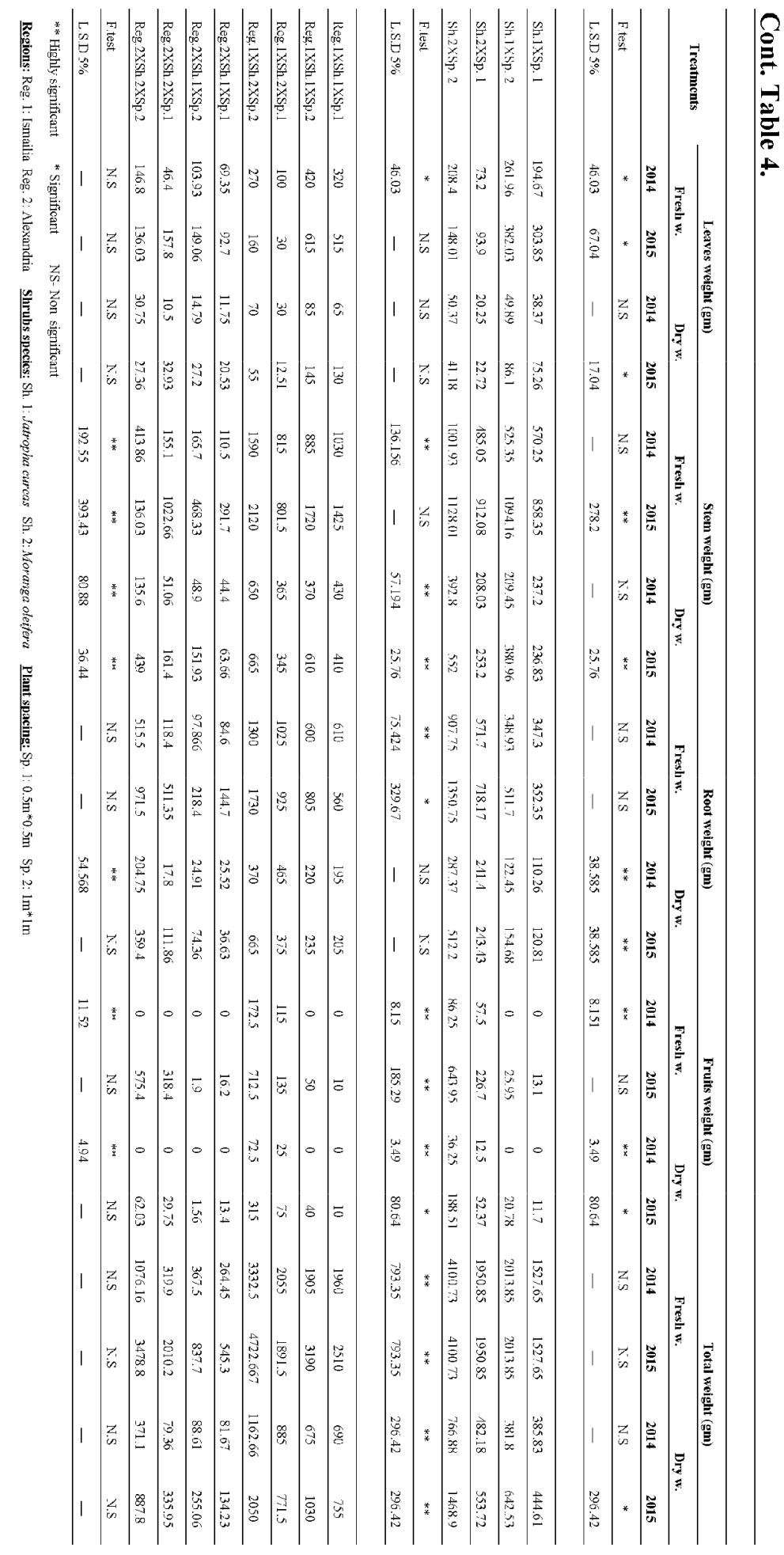


Table 5. The total yield of fruit, seed and oil $\left(\mathrm{kg} \mathrm{ha}^{-1}\right)$ of Jatropha curcas and Moringa oleifera and the percentage of fruiting shrubs (\%) for all treatments at 2014 and 2015

\begin{tabular}{|c|c|c|c|c|c|c|c|c|c|c|}
\hline \multirow[t]{2}{*}{ Regions } & \multicolumn{2}{|c|}{ Treatments } & \multicolumn{2}{|c|}{$\begin{array}{c}\text { Fruits } \\
\left(\mathrm{kg} \mathrm{ha}^{-1}\right)\end{array}$} & \multicolumn{2}{|c|}{$\begin{array}{c}\text { Seeds } \\
\left(\mathrm{kg} \mathrm{ha}^{-1}\right)\end{array}$} & \multicolumn{2}{|c|}{$\underset{\left(\mathrm{kg} \mathrm{ha}^{-1}\right)}{\text { Oil }}$} & \multicolumn{2}{|c|}{$\begin{array}{c}\text { The percentage of } \\
\text { fruiting shrubs } \\
(\%)\end{array}$} \\
\hline & $\begin{array}{l}\text { Shrubs } \\
\text { species }\end{array}$ & $\begin{array}{c}\text { Plant } \\
\text { spacing }\end{array}$ & 2014 & 2015 & 2014 & 2015 & 2014 & 2015 & 2014 & 2015 \\
\hline \multirow{4}{*}{ Ismailia } & \multirow{2}{*}{$\begin{array}{l}\text { Jatropha } \\
\text { curcas }\end{array}$} & $\begin{array}{c}0.5 \mathrm{~m} * \\
0.5 \mathrm{~m}\end{array}$ & 0 & 191 & 0 & 105 & 0 & 13.37 & 0 & 43 \\
\hline & & $1 \mathrm{~m} * 1 \mathrm{~m}$ & 0 & 169 & 0 & 93 & 0 & 12 & 0 & 77 \\
\hline & \multirow{2}{*}{$\begin{array}{c}\text { Moringa } \\
\text { oleifera }\end{array}$} & $\begin{array}{c}0.5 \mathrm{~m} * \\
0.5 \mathrm{~m}\end{array}$ & 1821 & 2111 & 536 & 621 & 70 & 82 & 53 & 60 \\
\hline & & $1 \mathrm{~m} * 1 \mathrm{~m}$ & 544 & 829 & 160 & 244 & 21 & 32 & 53 & 60 \\
\hline \multirow{4}{*}{ Alexandria } & \multirow{2}{*}{$\begin{array}{c}\text { Jatropha } \\
\text { curcas }\end{array}$} & $\begin{array}{c}0.5 \mathrm{~m} * \\
0.5 \mathrm{~m}\end{array}$ & 0 & 145 & 0 & 80 & 0 & 14 & 0 & 43 \\
\hline & & $1 \mathrm{~m} * 1 \mathrm{~m}$ & 0 & 0 & 0 & 0 & 0 & 0 & 0 & 0 \\
\hline & \multirow{2}{*}{$\begin{array}{c}\text { Moringa } \\
\text { oleifera }\end{array}$} & $\begin{array}{c}0.5 \mathrm{~m} * \\
0.5 \mathrm{~m}\end{array}$ & 0 & 1182 & 0 & 304 & 0 & 28 & 0 & 40 \\
\hline & & $1 \mathrm{~m} * 1 \mathrm{~m}$ & 0 & 552 & 0 & 142 & 0 & 13 & 0 & 60 \\
\hline
\end{tabular}

It was clear that Moringa was start give fruits at 2014 in Ismailia region with the two plant spacing. While, Jatropha start give fruits at 2015 in the two regions.

Although, Jatropha did not gave fruits with wide spacing in Alexandia region. But, Jatropha had the optimal fruiting shrubs percentage $(77 \%)$ in Ismailia with wide spacing, followed by Moranga in the two region which it gave $(60 \%)$ of fruiting shrubs percentage with wide spacing (Table, 5). The wider plant spacing of $1 \mathrm{~m} * 1 \mathrm{~m}$ exhibits minimum competition for growth factors therefore, did not affect the performance of individual plants (Amaglo et al., 2006). In addition, the ideal ecological characters for fast fruiting and the percentage of fruiting shrubs.

\section{CONCLUSION}

The experiment was conducted at two regions, two species and two plant spacing, results showed that Ismailia region had higher values for most of the growth parameters and the yield; therefore, it is ideal for planting and survival of Jatropha and Moringa. It was clear that, Moringa oleifera had a high growth parameters and yield as compared with Jatropha curcas. On the other side, closer plant spacing $\left(0.5 \mathrm{~m}^{*}\right.$ $0.5 \mathrm{~m})$, produced plants with greater height, fruits, seeds and oil yield, while wider plant spacing $\left(1 \mathrm{~m}^{*} 1 \mathrm{~m}\right)$, gave plants with bigger stem diameter, biomass and fruiting shrubs percentage. However, Jatropha curcas gave the highest oil percentage in Alexandria region with narrow spacing only, but it gave the superior fruiting shrubs percentage and fruits yield in Ismailia region with narrow and wide spacing.
So, Ismailia region is recommended for planting Jatropha and Moringa to gives better growth, high production and oil percentage.

\section{REFERENCES}

Achten, W. M. J., L.Verchot, Y. J. Franken, E. Mathijs, V. P. Singh, R. Aerts and B. Muys. 2008. Jatropha biodiesel production and use. Biomass Bioenergy. 32(12), 10631084.

Achten, W. M., W. Maes, R. Aerts, L.Verchot, A. Trabucco, E. Mathijs, V. Singh and B. Muys .2010. Jatropha: From global hype to local opportunity. J. Arid Environ. 74,1, $164-165$.

Amaglo, N. K., G. M. Timpo, W. O. Ellis, and R. N. Bennett. 2006. Effect of spacing and harvesting frequency on the growth and leaf yield of Moringa (Moringa oleifera Lam), a leafy vegetable crop. Moringa and other highly nutritious plant resources: Strategies, standards and markets for better impact on nutrition in Africa. Accra, Ghana, November 16-18, 2006. Pp 2 - 11.

Amouri, M., T. A. Zaïd, M. A. Aziza and O. Zanndouche. 2012. Life cycle analysis of Moringa oleifera biodiesel. VIème Congrès International sur les Energies Renouvelables et l'Environnement. 19-21 Mars, 2012, Hammamet, Tunisie.

Bernardo, A. L., M. G. F. Reis, G. G. Reis, R. B. Harrison and D. J. Firme. 1999. Effect of spacing on growth and biomass distribution in Eucalyptus camaldulensis, E. pellita and E. urophylla plantations in southeastern Brazil. Retrieved August 24, 2011 from $\mathrm{http}: / / \mathrm{www}$. sciencedirect.com/science? 
DaSchio, B. 2010. Jatropha curcas L. a potential bioenergy crop. On field research in Belize. M.Sc.dissertation. Padua University, Italy and Wageningen University and Research Centre, Plant Research International, the Netherlands. pp. $20-23$.

De Avila, J. G. 1949. Breves instruçoes para a cultura da purgueira. Colonia de Cabo Verde. Repartiçao Técnica dos Serviços Agrícolas, Florestais e Pecuários. Imprensa Naçional de Cabo Verde, Praia.

Deng, X., Z. Fang and Y. H. Liu. 2010. "Ultrasonic Transesterification of Jatropha curcas L. Oil to Biodiesel by a Two-Step Process." Energy Convers. Manage. 51: 2802-2807.

Edward, E., S.A.O. Chamshama and A.G. Mugasha. 2006. Growth performance of lesser-known Leucaena species/provenances at Gairo inlang plateau, Morogoro, Tanzania. South. Afr. For. J. 208:53-62.

Edward, E., S. A. O. Chamshama, M. A. Mndolwa and Y. M. Ngaga. 2013. Effect of spacing and cutting management on survival, growth and biomass production of Moringa oleifera intercropped with maize on-station at Gairo inland plateau and Ruvu, Coast region - Tanzani. Greener Journal of Agricultural Sciences. ISSN: 2276-7770. Vol. 3 (4), pp. 254-261.

Eijck, J. 2007. Transition towards Jatropha biofuels in Tanzania? An analysis with Strategic Niche Management. $20 \mathrm{pp}$.

Evangelista, A. 2009. Response of Jatropha (Jatropha curcas) to the combination of nitrogen, phosphorus and potassium fertilization and arbuscular mycorrhiza inoculation in four soil types in Samar Provinces, Philippines. Abstract Philippine Journal of Crop Science. 34(1): 48.

Fagam, A. S., O. O. Benjamin, M. S. Yunusa and J. I. Dantata. 2012. Effects of fertilizer types and plant spacing on the growth parameters and dry matter yield in Jatropha curcus L. Journal of Science, Technology \& Education Vol. 1, No. 2, December, 2012.

FAO. 2011. OIL TREES FOR ENERGY IN THE NEAR EAST REGION, FAO. 2011. Ecocrop. Available at http://ecocrop.fao.org/ecocrop/srv/en/cropView?id=9786.

Ghosh, A., J. S. Patolia, D. R. Chaudhary, J. Chikara, S .N. Rao, D. Kumar, G. N. Boricha and A. Zala. 2006. Response of Jatropha curcas under different spacing to Jatropha de-oiled cake. Soil Condition and Fertilization 34: $29-35$.

Harper, J. L. 1977. Population Biology of Plants. Academic Press.

Heller, J. 1996. Physic nut. Jatropha curcas L. Promoting the conservation and use of underutilized and neglected crops. 1. $\mathrm{PhD}$ [dissertation].Gatersleben, Germany/Rome, Italy: Institute of Plant Genetics and Crop Plant Research/ International Plant Genetic Resources Institute. (accessed on 11 May 2015).

IFAD - FAO. 2010. Jatropha: A Smallholder Bioenergy Crop The Potential for Pro-Poor Development. Integrated Crop Management Vol. 8- 2010.
Jongschaap, R. E. E., W. J. Corré, P. S. Bindraban and W. A. Brandenburg. 2007. Claims and Facts on Jatropha curcas L. Wageningen, Plant Research International.

Kalannaver, V. N., S. S. Angadi, V. C. Patil, A. S. Byadagi, S. Z. Batil and S. Angadi. 2009. Effect of major nutrients on growth and yield of Jatropha curcas L.) Karnataka Journal of Agricultural Science. 22(5): 1095-1096.

Krishna, K. M., G. N. Prabhakar, M. V. R. Subrahmanyam and A. S. Sankar. 2008. Studies on growth performance of Jatropha (Jatrophacurcas L.) under pruning and sources of nutrients. Journal Research of Angrau. 36(4): 1-4.

Ministry of Agriculture and land Reclamation Under secretariat for Afforestation \& Environment. 2009. The national program for safe use of treated wastewater for afforestation, June 2009.

Öğütçü, Z. 1980. Hintyaği bitkisi Ricinus communis L. Türkiye'de gelişme ve yetişme olanakları. Hinttaş Hitit Ziraat ve Nebati Yağ Sanayii, Anonim Şirketi Yayınları, 3, 150 s. Ankara.

Palada, M. C. and L. C. Chang. 2003. Suggested Cultural Practices. Moringa 3(545):1-5.

Radovich, T. 2009. Farm and Forestry Production and Marketing profile for Moringa (Moringa oleifera) Specialty Crops for Pacific Island Agroforestry [http://a groforestry.net/scps] site visited on 1/6/2011.

Ramachandran, C., K.V. Peter and P. K. Gopalakrishnan. 1980. Drumstick (Moringa oleifera): A Multipurpose Indian Vegetable. Economic Botany 34(3): 276 - 283.

Rashid, U., F. Anwar, B. R. Moser and G. Knothe. 2008. Moringa oleifera oil: A possible source of biodiesel, Bioresource Technology 99: 8175-8179.

Reddy, A. R., K. R. Reddy, R. Padjung and H. F. Hodges. 1996. Nitrogen nutrition and photosynthesis in leaves of Pima. J.Plant Nutr. 19: 755-770.

Saxena, S. C., H. S. Manral and A. S. Chandel. 2001.Effect of inorganicand organic sources of nutrients on soybean (Glycine max).Indian Journal of Agronomy. 46:135-140.

Shams, A., M. A. Moursi and S. S. Ahmed. 1967. Effects of nitrogen and spacing on castor bean in sandy soils in Egypt. Cairo University. U.A.R. National Research Centre and Faculty of Agriculture, Experimental Agriculture/Volume 4/ Issue 01/ January 1968, pp. 61-64.

Silitonga, A. S., A. E. Atabania, T. M. I. Mahliaa, H. H. Masjukia, I. A. Badruddina and S. Mekhilefe. 2011. Renewable and Sustainable A review on prospect of Jatropha curcas for biodiesel in Indonesia. Energy Reviews 15: 3733-3756.

Silva, M. B. R., P. D. Fernandes, J. Dantas Neto, A. R. Nery, L. N. Rodrigues and R. A. Viégas. 2011. Crescimento e produção do pinhão manso irrigado com água residuária sob condições de estresse hídrico. Revista Brasileira de Engenharia Agrícola e Ambiental, v.15, p.621-629, http://dx.doi.org/10.1590/S1415 43662011000600013.

Snedecor, G. W. and W. G. Cochran. 1989. Statistical Methods, Eighth Edition, Iowa State Univ. Press Ames, Iowa, USA. 
Terren, M., S. Saverys, P. Jacquet de Haveskercke, S. Winandy and G. Mergeai .2012. Attempted Cultivation of Jatropha curcas L. in the Lower Senegal River Valley: Story of a Failure. TROPICULTURA, 30, 4, 204-208.

Tewari, D. N. 2007. Jatropha and biodiesel. 1st ed. New Delhi: Ocean Books Ltd.

Tilman, D., P. B. Reich and J. M. H. Knops. 2006. "Biodiversity and ecosystem stability in a decade-long grassland experiment”. Nature 441: 629632.
Verma A. K., R. R. Dash and P. Bhunia. 2012. A review on chemical Coagulation/ flocculation technologies for removal of colour from textile wastewaters. Journal of Environmental Management 93: 154 - 168.

Water Research Commission. 2008. The potential of the impact of large-scale planting of the biofuel crop Jatropha curcas was investigated. Jatropha curcas: Measuring the Impact of Large-scale Planting on Water Resources, South Africa. 2pp.

World Meteorological Organization (UN) 27-09-2009.

\section{المالخص المصي}

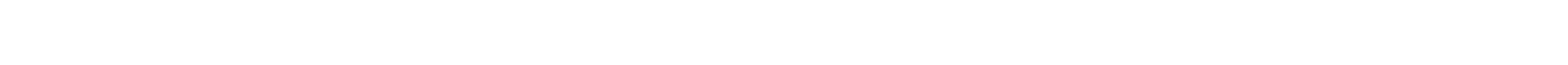

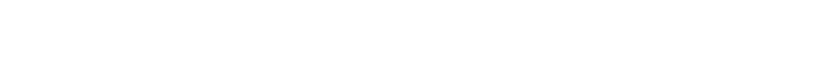

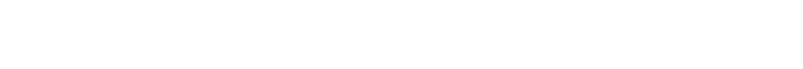

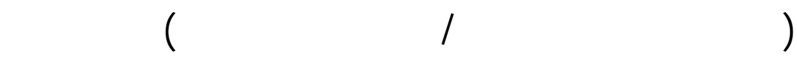

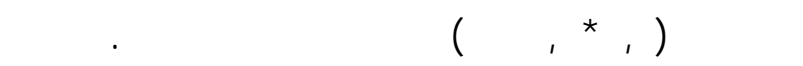

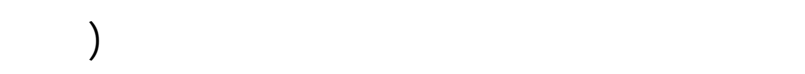

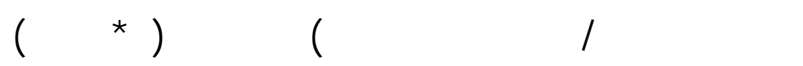

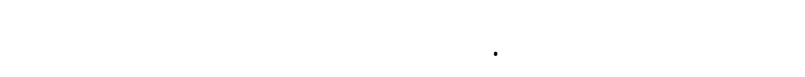

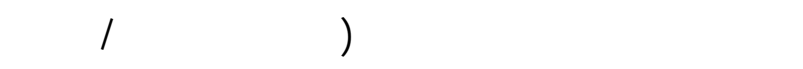

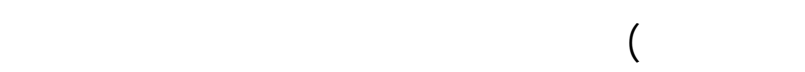

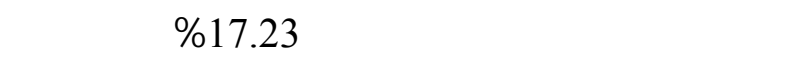

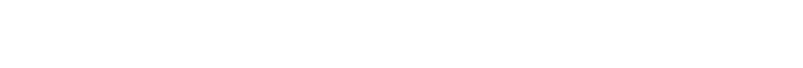
الضيقة تليها مطقة الأسماعيلية.

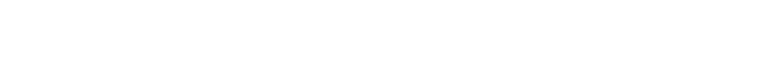

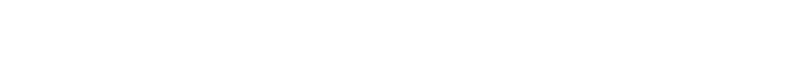

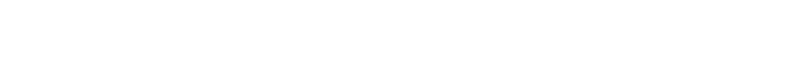

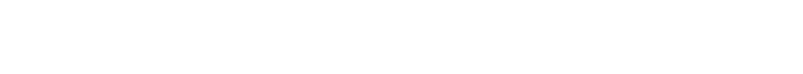
المنزرعة على المسفلت الضيقة.

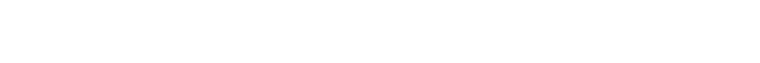

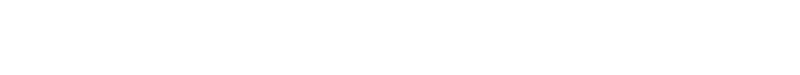

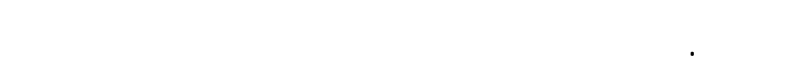

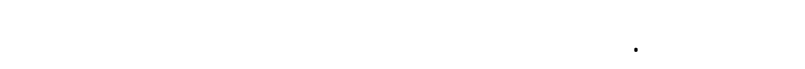

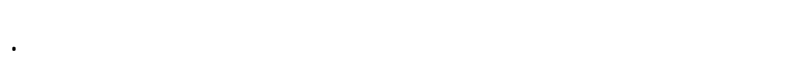

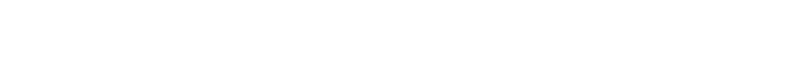

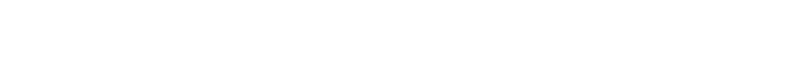

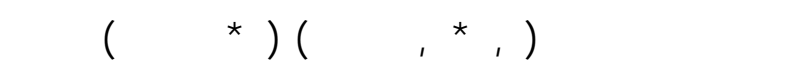

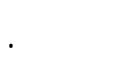

لظٔلهرت النتائج أختلافات معنوية عالية لمظم مق ابيس

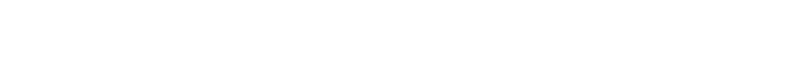

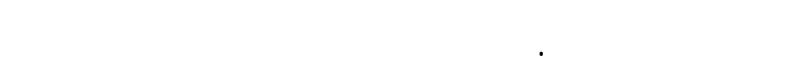

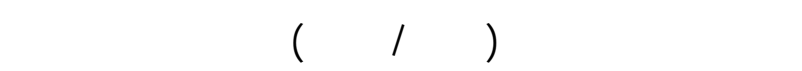

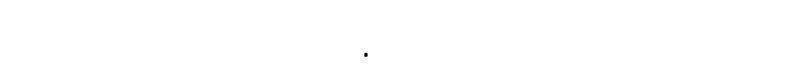

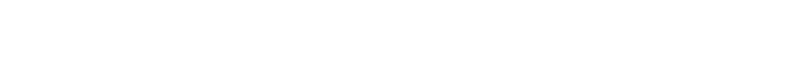

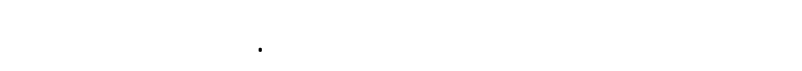

